University of Nebraska - Lincoln

DigitalCommons@University of Nebraska - Lincoln

Nebraska Game and Parks Commission -- Staff

Research Publications

Nebraska Game and Parks Commission

2002

\title{
Effects of Predation and Environment on Quality of Yellow Perch and Bluegill Populations in Nebraska Sandhill Lakes
}

Craig P. Paukert

South Dakota State University

David W. Willis

South Dakota State University

Joel A. Klammer

Nebraska Game and Parks Commission

Follow this and additional works at: https://digitalcommons.unl.edu/nebgamestaff

Part of the Environmental Sciences Commons

Paukert, Craig P.; Willis, David W.; and Klammer, Joel A., "Effects of Predation and Environment on Quality of Yellow Perch and Bluegill Populations in Nebraska Sandhill Lakes" (2002). Nebraska Game and Parks Commission -- Staff Research Publications. 49.

https://digitalcommons.unl.edu/nebgamestaff/49

This Article is brought to you for free and open access by the Nebraska Game and Parks Commission at DigitalCommons@University of Nebraska - Lincoln. It has been accepted for inclusion in Nebraska Game and Parks Commission -- Staff Research Publications by an authorized administrator of DigitalCommons@University of Nebraska - Lincoln. 


\title{
Effects of Predation and Environment on Quality of Yellow Perch and Bluegill Populations in Nebraska Sandhill Lakes
}

\author{
Craig P. Paukert* and David W. Willis \\ Department of Wildlife and Fisheries Sciences, Post Office Box 2140B, \\ South Dakota State University, Brookings, South Dakota 57007, USA \\ Joel A. KLAMmer \\ Nebraska Game and Parks Commission, Post Office Box 508, \\ Bassett, Nebraska 68714, USA
}

\begin{abstract}
We investigated factors that may influence the quality (e.g., high abundance, size structure, condition, and growth) of yellow perch Perca flavescens and bluegill Lepomis macrochirus populations in Nebraska sandhill lakes. Physical (e.g., lake depth, vegetation coverage), chemical (e.g., alkalinity, conductivity), and biological (e.g., chlorophyll $a$, invertebrate abundance) characteristics of 30 natural lakes were determined in 1998 and 1999. Growth, condition, and size structure were not density-dependent for bluegills or yellow perch in these shallow $(<4$ m maximum depth) lakes. However, bluegill abundance, size structure, and condition were positively related to yellow perch abundance, size structure, and condition. Bluegill quality tended to increase with increased emergent vegetation, whereas yellow perch quality was not correlated with any physicochemical variable measured. Submergent vegetation coverage ranged from $5 \%$ to $97 \%$ of lake surface area and was not related to panfish quality. The mean relative weight $\left(W_{r}\right)$ of larger $(15-$ $20 \mathrm{~cm}$ ) bluegills was positively associated with high Daphnia and Cyclops abundance, whereas the mean $W_{r}$ of 20-25-cm yellow perch was not related to invertebrate abundance. Higher relative abundance and lower proportional stock density of largemouth bass Micropterus salmoides were positively related to panfish quality, even in lakes up to 341 ha. Quality panfish populations in the Nebraska sandhills are influenced by predators, prey, and the environment. However, based on the high correlation coefficients, largemouth bass may be most influential in structuring the quality of bluegill and yellow perch populations in these shallow natural lakes.
\end{abstract}

Schneider (1999) suggested that Midwestern lakes often contain panfish populations that exhibit slow growth and low size structure. Such lakes may have lower numbers of preferred-length panfish (i.e., 20-cm bluegill Lepomis macrochirus and 25-cm yellow perch Perca flavescens [Gabelhouse 1984]) than lakes with lower panfish abundance. However, bluegill populations in some water bodies are capable of having high size structure (i.e., up to $62 \%$ of bluegills $>20 \mathrm{~cm}$; Schneider 1999) and relatively high density (up to 504 fish/ha; Schneider 1999).

Panfish quality, which we define as high relative abundance, size structure, condition, and growth in a given lake when compared to other natural lakes in the Nebraska sandhills, can be affected by the physical and chemical environment of lakes. Fish production and yield have been linked to alkalinity (Hayes and Anthony 1964), phosphorus (Hanson and Leggett 1982), the morphoedaphic index (MEI; defined as total dissolved solids/mean

\footnotetext{
* Corresponding author: Craig_Paukert@sdstate.edu
}

Received September 27, 2000; accepted May 9, 2001 lake depth; Ryder 1965; Jenkins 1982), and chlorophyll $a$ (Jones and Hoyer 1982). Bluegill size structure increased with alkalinity in relatively undisturbed Mississippi lakes (Jackson and BrownPeterson 1997), and growth was faster in shallow, alkaline Minnesota lakes than deepwater Minnesota lakes (Tomcko 1997). However, these studies typically did not focus on quality panfish populations.

Submergent vegetation coverage may influence the growth of bluegills and yellow perch (Theiling 1990; Lott 1991; Trebitz et al. 1997). In addition, lakes with submergent vegetation coverage may allow higher panfish abundance (Lucchesi 1991; Hinch and Collins 1993) and a lower proportion of larger fish (Colle et al. 1987) than lakes with limited submergent vegetation. However, submergent vegetation coverage may not be detrimental to bluegill populations in some water bodies (Schneider 1999). Although high submergent vegetation coverage may reduce predation on panfish, and increased abundance may lead to intraspecific competition, emergent vegetation has also been related to panfish quality (Paukert and Willis 2000). 
Predators often affect panfish population quality. The proportion of large bluegills (i.e., $\geq 15 \mathrm{~cm}$ ) and yellow perch (i.e., $\geq 20 \mathrm{~cm}$ ) increased with increasing abundance of largemouth bass Micropterus salmoides in small Midwestern impoundments (Anderson 1976; Guy and Willis 1990, 1991). However, these relationships have rarely been documented for large (i.e., $>30$ ha) natural water bodies. In many Midwestern lakes and ponds, increased bluegill abundance leads to slower growth (Weiner and Hanneman 1982) and a lower proportion of larger bluegills $(>15 \mathrm{~cm}$; Novinger and Legler 1978). However, Tomcko (1997) did not find an inverse relationship between bluegill relative abundance and growth in Minnesota lakes. Information is needed on the effects of predators and intraspecific competition on panfish quality in larger water bodies, so that biologists can make informed management decisions to increase panfish quality in these lakes.

The Nebraska sandhill lakes typically have high panfish quality, defined as fish condition above the 75th percentile across the species range and growth to sizes preferred by anglers in less than 5 years (Paukert and Willis 2000). However, some sandhill lakes produce panfish that attain faster growth, higher condition, and higher size structure than other sandhill lakes. Therefore, our objectives were to evaluate which factors affected the quality of bluegill and yellow perch populations. We indexed quality using relative abundance, size structure, condition, and growth. In particular, we determined the effects of predators and environmental factors on the quality of bluegill and yellow perch populations in an ecosystem that typically has high-quality panfish.

\section{Methods}

Study area.-Thirty natural lakes were sampled in the sandhill region in northcentral Nebraska in 1998 and 1999. These lakes depend on groundwater and surface water drainage, with many having flowing springs and seepages. Although the lakes may have 2-3 months of ice cover, winterkills are limited (McCarraher 1977) because of the flowing springs. Lakes varied in surface area from 15 to 907 ha and were shallow (maximum depth, $1.5-4.0 \mathrm{~m}$ ) and almost entirely littoral (mean depth, 1.0-2.9 m). Submergent vegetation coverage ranged from $4 \%$ to $97 \%$ (mean, $48 \%$ ). Secchi disk transparency was highly variable (14-258 $\mathrm{cm}$ ), and total alkalinity ranged from 85 to 447 $\mathrm{mg} / \mathrm{L}$.

Twenty-nine of the 30 lakes contained yellow perch, whereas 22 lakes contained bluegills. Largemouth bass were present in 22 lakes, northern pike Esox lucius in 16, black bullhead Ameiurus melas in 25, and common carp Cyprinus carpio in 9 of the lakes. Few small fishes that may serve as prey, such as small cyprinids, were found in these lakes, with golden shiners Notemigonus crysoleucas found in only 11 waters. Ranching is the most common land use in the sandhills, and 9 lakes were located within national wildlife refuges. Angler exploitation is presumably minimal; winter creel surveys suggested that bluegill exploitation from Valentine National Wildlife Refuge lakes is less than 10\% (Nebraska Game and Parks Commission, unpublished data). Little angling effort occurs during the summer because of the extensive vegetation coverage. Three lakes were closed to fishing, and most of the 30 lakes were either on private land or difficult to access.

Fish sampling.-Largemouth bass were sampled by pulsed-DC (200-250 V, 3-6 A) nighttime electrofishing at 12 randomly selected 10-min stations, from 15 May to 23 June 1998 and from 2 May to 24 June 1999. Catch per unit effort (CPUE) of largemouth bass was expressed as the number of fish $20 \mathrm{~cm}$ or larger collected per hour of electrofishing. Fifteen lakes were sampled each year, for a total of 30 lakes. All other fish species were sampled at randomly selected locations with overnight sets of double-throated trap nets (i.e., modified fyke nets) with 16-mm-bar measure mesh, $1.1-\mathrm{m} \times 1.5-\mathrm{m}$ frames, and $22-\mathrm{m}$ leads. Total sampling effort was 10 trap-net nights in lakes smaller than 50 ha and 20 trap-net nights in lakes 50 ha or larger. Yellow perch and bluegill CPUE was expressed as the number of stock-length (CPUE$\mathrm{S})$ and preferred-length (CPUE-P) fish, where stock and preferred bluegills were 8 and $20 \mathrm{~cm}$ total length (TL) and stock and preferred yellow perch were 13 and $25 \mathrm{~cm}$ TL (Gabelhouse 1984). Northern pike CPUE was expressed as the number of stock-length fish $(\geq 35 \mathrm{~cm})$ collected per trapnet night.

Scales for age and growth analyses were taken from 10 individuals per $1.0-\mathrm{cm}$ length-group for bluegills and yellow perch. These fish were weighed to the nearest gram and measured for TL to the nearest millimeter. All additional fish were tallied by $1.0-\mathrm{cm}$ length-group by species.

Mean length at age for bluegills and yellow perch was fitted to a nonlinear least-squares regression model (assuming additive errors) with the von Bertalanffy growth function (Ricker 1975). We then used the models to estimate growth as the 
time in years for bluegills and yellow perch to reach preferred length. Fish condition was quantified as relative weight $\left(W_{r}\right)$ for $15-20-\mathrm{cm}$ bluegills and $20-25-\mathrm{cm}$ yellow perch, based on standard weight equations summarized by Anderson and Neumann (1996). We omitted length-groups that contained less than three fish from the $W_{r}$ analysis. The size structure of the fish populations was quantified in terms of the proportional stock density (PSD) and the relative stock density of preferred-length fish (RSD-P) (Anderson and Neumann 1996) for population samples containing at least 20 stock-length fish.

Biological sampling.-Chlorophyll $a$, zooplankton, and macroinvertebrates were sampled 2-26 July 1998 (for the 15 lakes sampled for fishes in 1998) and 1-24 July 1999 (for the 15 lakes sampled for fishes in 1999) at four locations in each of the 30 lakes. Chlorophyll $a$ was estimated from duplicate samples of four offshore water samples collected with a 2-m-long vertical tube sampler. Samples were filtered through glass fiber filters in the field and extracted in the laboratory by methods described by Lind (1985). Zooplankton were collected as two replicates at each of four offshore sites using a 2-m-long tube sampler (Rabeni 1996) filtered through a $65-\mu \mathrm{m}-\mathrm{mesh}$ net. Macroinvertebrates were sampled with an Ekman dredge. Three samples of macroinvertebrates were collected at each of the four sites in each lake and were hand-sieved in the field. In the laboratory, zooplankton were identified to genus and counted, and a maximum of 120 individuals of each genus was measured. Macroinvertebrates were identified to family and counted.

Physical and chemical sampling.-During the same time that the biological sampling was conducted, alkalinity and total phosphorus were estimated with Hach kits, and total dissolved solids were recorded $0.5 \mathrm{~m}$ below the surface with an electronic meter. Secchi disk transparency was measured at four locations in each lake in July during midday. Topographical maps and aerial photographs were used to calculate the shoreline development index (SDI; Lind 1985).

Vegetation and substrate were quantified for all 30 lakes in July 1999 at five to seven transects evenly spaced across each lake. At 50-200-m intervals (depending on lake size) along each transect, vegetation within a $1-\mathrm{m}^{2}$ grid beside the boat was classified as either emergent, submergent, or floating. The percent coverage of each vegetation class was calculated as the number of sites of that class divided by the total number of sites sampled across all transects in the lake (Paukert and Willis 2000).

Mean lake depth was calculated using measurements (nearest $0.1 \mathrm{~m}$ ) taken at each of the vegetation and substrate sites. Mean depth was calculated by dividing the sum of all the depth measurements for each lake by the number of sites in each lake. We then calculated MEI from our total dissolved solids and mean lake depth measurements.

Statistical analyses.-Principal components analysis (PCA) was used to reduce the dimensionality of our panfish, productivity, and invertebrate abundance parameters into simpler indices (Johnson 1998). In the panfish analyses, we incorporated our four indices of panfish quality (CPUE-P, RSD-P, mean $W_{r}$, and time to reach preferred length) for bluegills and yellow perch separately. We then interpreted the principal component (PC) axis (PC1, PC2, or PC3) as combinations of our panfish quality indices. We also used PCA to analyze our physicochemical variables (Secchi depth, chlorophyll $a$, total phosphorus, MEI, total alkalinity, SDI, and lake area) and our invertebrate abundance data (Bosmina, Chydorus, Cyclops, Daphnia, amphipods, chironomids, gastropods, oligochaetes, and pelecypods). In all PC analyses, we interpreted only axes with eigenvalues greater than 1.0 (Johnson 1998).

We used Pearson correlations or, when the data were not normally distributed, Spearman rank correlations to determine the strength of the relationships between the principal component scores of our panfish quality, physicochemical, and invertebrate abundance PCAs. To investigate the relationship between panfish quality and predator (largemouth bass and northern pike) CPUE and PSD as well as emergent and submergent vegetation coverage, we correlated bluegill and yellow perch principal components directly with these variables. To control our family-wise error rate for multiple correlations, we used a Bonferroni correction (Sokal and Rohlf 1995) to adjust our alpha level for all correlations. We also sought to determine which variable explained most of the variation in our panfish PC indices. To do this, we used multiple regression and a maximum $R^{2}$ selection procedure (Freund and Littell 1991), with panfish PC scores as the dependent variables and physicochemical and invertebrate PC scores, vegetation, and largemouth bass CPUE and PSD as independent variables. Northern pike were not included in these analyses because of insufficient sample size. All statistical analyses were performed in SAS (SAS 
TABLE 1.-Means, medians, lower quartiles, upper quartiles, and number of lakes of the fish community characteristics measured in Nebraska sandhill lakes, 1998-1999. The following abbreviations are used: CPUE-P = catch per unit effort of preferred-length fish (number of fish per trap-net night for bluegills and yellow perch, number of fish per hour of electrofishing for largemouth bass); RSD-P = relative stock density of preferred-length fish; $W_{r}=$ relative weight; and PSD = proportional stock density. The preferred length is $20 \mathrm{~cm}$ for bluegills and $25 \mathrm{~cm}$ for yellow perch. Time to reach preferred length was estimated using von Bertalanffy growth functions.

\begin{tabular}{|c|c|c|c|c|c|}
\hline Species and variable & Mean (SD) & Median & $\begin{array}{c}\text { Lower } \\
\text { quartile }\end{array}$ & $\begin{array}{c}\text { Upper } \\
\text { quartile }\end{array}$ & $\begin{array}{l}\text { Number } \\
\text { of lakes }\end{array}$ \\
\hline \multicolumn{6}{|l|}{ Bluegill } \\
\hline CPUE-P & $4.3(5.9)$ & 2.1 & 0.7 & 3.9 & 21 \\
\hline RSD-P & $17 \quad(18)$ & 11 & 6.5 & 22 & 20 \\
\hline Mean $W_{r}(15-20 \mathrm{~cm})$ & $120 \quad(12)$ & 118 & 112 & 123 & 21 \\
\hline Time to reach preferred length & $5.9(2.2)$ & 5.1 & 4.7 & 6.1 & 19 \\
\hline \multicolumn{6}{|l|}{ Yellow perch } \\
\hline CPUE-P & $3.7(8.0)$ & 0.5 & 0.1 & 2.0 & 19 \\
\hline RSD-P & $17 \quad(23)$ & 7 & 2 & 18 & 25 \\
\hline Mean $W_{r}(20-25 \mathrm{~cm})$ & $90 \quad(9)$ & 89 & 82 & 98 & 25 \\
\hline Time to reach preferred length & $5.6(2.1)$ & 4.9 & 4.3 & 6.5 & 22 \\
\hline \multicolumn{6}{|l|}{ Largemouth bass } \\
\hline CPUE $\geq 20 \mathrm{~cm}$ & $66.7(54.4)$ & 48.9 & 15.5 & 117.5 & 22 \\
\hline PSD & $58 \quad(21)$ & 57 & 39 & 73 & 20 \\
\hline
\end{tabular}

Institute 1996) with a significance level set a priori at 0.05 .

\section{Results}

Bluegill and yellow perch populations in the $\mathrm{Ne}$ braska sandhill lakes exhibited variable abundance, growth, condition, and size structure (Table 1). However, few of these lakes contained lowquality panfish populations. Bluegill CPUE-P ranged from 0 to 18.5 , whereas yellow perch CPUE-P ranged from 0 to 33.3. Size structure (RSD-P) was generally high (mean $=17$ for both bluegills and yellow perch) and ranged from 0 to 74 for bluegill and from 0 to 76 for yellow perch. Mean $W_{r}$ for 15-20-cm bluegills ranged from 94 to 146 , with only two populations having mean $W_{r}$ values less than 100; the mean for all populations was 120 . Mean $W_{r}$ for 20-25-cm yellow perch was lower (90) and ranged from 77 to 105 . Only one lake contained a high-density (80 stock-length fish per trap-net night), slow-growing (14 years to reach preferred length) bluegill population. The time it took to reach preferred length ranged from 4.3 to 14 years (mean, 5.9) for bluegills and from 3.5 to 11.2 years (mean, 5.6) for yellow perch (Table 1).

\section{Principal Component Analysis Interpretations}

Panfish population characteristics (i.e., relative abundance, size structure, and growth) were typically associated with one another. Bluegill CPUE$\mathrm{P}$ and RSD-P component loadings were high on bluegill PC1, and the time to reach preferred length had a high negative loading on PC1 (Table 2). Bluegill populations with higher relative abundance, size structure, and growth scored higher on PC1. Bluegill mean $W_{r}$ had a high negative loading on PC2 (Table 2), suggesting this axis was an index of condition. Yellow perch PC1 had high component loadings of CPUE-P and RSD-P, whereas

TABLE 2.-Loadings for the principal components (PC) analyses of the bluegill and yellow perch populations in the Nebraska sandhill lakes. CPUE-P = catch per unit effort of preferred-length fish; RSD-P = relative stock density of preferred-length fish; and $W_{r}=$ relative weight. The eigenvalues and percent variance explained by each axis are given at the bottom of the table. Quality length is $15 \mathrm{~cm}$ for bluegills and $20 \mathrm{~cm}$ for yellow perch; preferred length is $20 \mathrm{~cm}$ for bluegills and $25 \mathrm{~cm}$ for yellow perch.

\begin{tabular}{lcccccc}
\hline \multirow{2}{*}{\multicolumn{1}{c}{ Variable }} & \multicolumn{2}{c}{ Bluegills } & & \multicolumn{2}{c}{ Yellow perch } \\
\cline { 2 - 3 } \cline { 6 - 7 } \cline { 5 - 6 } & & PC1 & PC2 & & PC1 & PC2 \\
\hline CPUE-P & 0.55 & 0.51 & & 0.54 & 0.54 \\
RSD-P & 0.51 & 0.19 & & 0.59 & 0.31 \\
Mean $W_{r}$ (quality-preferred) & 0.36 & -0.81 & & 0.42 & -0.62 \\
Time to reach preferred length & -0.48 & & 0.22 & & -0.44 & 0.48 \\
Eigenvalue & 1.82 & 0.97 & & 2.17 & 0.83 \\
Percent variance explained & 46 & 24 & & 54 & 21 \\
\hline
\end{tabular}


TABLE 3.-Loadings for the first three principal component (PC) axes of the physicochemical principal components analysis for Nebraska sandhill lakes. The eigenvalues and percent variance explained by each axis are given at the bottom of the table. The morphoedaphic index $=$ total dissolved solids/mean lake depth.

\begin{tabular}{lrrr}
\hline \multicolumn{1}{c}{ Variable } & PC1 & PC2 & PC3 \\
\hline Secchi depth & 0.02 & -0.67 & -0.26 \\
Chlorophyll $a$ & -0.43 & 0.29 & 0.46 \\
Total phosphorus & -0.45 & 0.11 & 0.14 \\
Morphoedaphic index & 0.44 & -0.26 & 0.52 \\
Total alkalinity (mg/L) & 0.50 & 0.13 & 0.45 \\
Shoreline development index & 0.27 & 0.25 & -0.38 \\
Lake area (ha) & 0.30 & 0.56 & -0.28 \\
Eigenvalue & 2.39 & 1.55 & 1.11 \\
Percent variance explained & 32 & 22 & 16 \\
\hline
\end{tabular}

mean $W_{r}$ had a high negative loading on yellow perch PC2 (Table 2). The time to reach preferredlength had a high negative loading on PC1 and a high positive loading on PC2; however, we interpreted this variable as a function of $\mathrm{PC} 1$ because this axis explained $33 \%$ more variation than PC2 (Table 2). Yellow perch populations with higher relative abundance, size structure, and growth were associated with high scores on PC1, whereas high yellow perch condition was associated with low PC2 axis scores.

Lakes with higher alkalinity and MEI values were typically associated with low chlorophyll $a$ and total phosphorus indices. Our physicochemical PCA revealed that PC1 had high negative component loadings of chlorophyll $a$ and total phosphorus and high positive MEI and total alkalinity loadings (Table 3). Principal component 3 only explained $16 \%$ of the variation and had high loadings of variables interpreted in PC1 and PC2 (Table $3)$.

Lakes with abundant zooplankton (i.e., Daphnia, Chydorus, and Cyclops) populations scored high on invertebrate PC1, whereas lakes with high macroinvertebrate (i.e., oligochaetes, amphipods, and pelecypods) abundance scored high on invertebrate PC2 (Table 4). Invertebrate PC1 and PC2 explained $22 \%$ and $21 \%$ of the variation, respec-
TABLE 4.-Loadings for the first three principal component (PC) axes of the invertebrate abundance principal components analysis for Nebraska sandhill lakes. The eigenvalues and percent variance explained by each axis are given at the bottom of the table. Zooplankton abundance is measured as number/L, macroinvertebrate abundance as number $/ \mathrm{m}^{2}$.

\begin{tabular}{lrrr}
\hline \multicolumn{1}{c}{ Invertebrate } & PC1 & PC2 & PC3 \\
\hline Zooplankta & & & \\
$\quad$ Bosmina & 0.29 & -0.46 & 0.26 \\
Chydorus & 0.40 & -0.42 & -0.28 \\
Cyclops & 0.46 & -0.03 & -0.27 \\
$\quad$ Daphnia & 0.46 & 0.09 & -0.37 \\
Macroinvertebrates & & & \\
$\quad$ Amphipods & -0.02 & 0.42 & -0.08 \\
Chironomids & 0.21 & -0.16 & 0.74 \\
Gastropods & -0.32 & -0.07 & -0.13 \\
$\quad$ Oligochaetes & 0.39 & 0.47 & 0.15 \\
$\quad$ Pelecypods & 0.24 & 0.42 & 0.23 \\
Eigenvalue & 1.93 & 1.89 & 1.25 \\
Percent variance explained & 22 & 21 & 14 \\
\hline
\end{tabular}

tively. Principal component 3 , which only explained $14 \%$ of the variation, was primarily an axis of chironomid abundance (Table 4).

\section{Inter- and Intraspecific Relationships}

Bluegill and yellow perch population characteristics exhibited similar trends. Bluegill PC1 was positively related to yellow perch PC1 $(r=0.57$, df $=11, P=0.04)$, and bluegill PC2 was positively related to yellow perch PC2 $(r=0.91$, df $=11, P<0.0001$ ).

The growth and condition of bluegills and yellow perch were not density dependent in Nebraska sandhill lakes. Mean CPUE of stock-length fish, an index of overall abundance, was not related to RSD-P, mean $W_{r}$, or the time to reach preferred length for bluegill or yellow perch (Table 5).

\section{Physicochemical and Vegetation Analyses}

Bluegill and yellow perch quality were not strongly related to aquatic vegetation or to the physicochemical variables measured. For bluegills, PC1 tended to increase with lake coverage of emergent vegetation (Table 6), but this rela-

TABLE 5.-Correlations between catch per unit effort (CPUE) of stock-length and longer yellow perch and bluegills and (1) the relative stock density of preferred-length fish (RSD-P), (2) mean relative weight $\left(W_{r}\right)$, and (3) time to reach preferred length.

\begin{tabular}{lcccccccc}
\hline & \multicolumn{3}{c}{ Bluegill CPUE } & & \multicolumn{3}{c}{ Yellow perch CPUE } \\
\cline { 2 - 5 } \cline { 7 - 9 } \multicolumn{1}{c}{ Variable } & $r$ & $P$ & $\mathrm{df}$ & & $r$ & $P$ & $\mathrm{df}$ \\
\hline RSD-P & -0.13 & 0.60 & 18 & & 0.11 & 0.59 & 23 \\
Mean $W_{r}$ & -0.26 & 0.25 & 19 & & -0.13 & 0.52 & 23 \\
Time to reach preferred length & -0.24 & 0.31 & 17 & & -0.09 & 0.69 & 20 \\
\hline
\end{tabular}


TABLE 6.-Correlations between bluegill and yellow perch principal components (PCs) and vegetation, physicochemical and invertebrate abundance PC axes scores, and catch per unit effort (CPUE) and proportional stock density (PSD) of largemouth bass (LMB) and northern pike (NOP). Only three lakes contained floating vegetation and were removed from further analyses. The significance level was set at 0.004 after Bonferroni corrections.

\begin{tabular}{|c|c|c|c|c|c|c|c|c|c|c|c|c|}
\hline \multirow[b]{3}{*}{ Variable } & \multicolumn{6}{|c|}{ Bluegill } & \multicolumn{6}{|c|}{ Yellow perch } \\
\hline & \multicolumn{3}{|c|}{ PC1 } & \multicolumn{3}{|c|}{$\mathrm{PC} 2$} & \multicolumn{3}{|c|}{ PC1 } & \multicolumn{3}{|c|}{$\mathrm{PC} 2$} \\
\hline & $r$ & $P$ & df & $r$ & $P$ & df & $r$ & $P$ & df & $r$ & $P$ & df \\
\hline \multicolumn{13}{|l|}{ Vegetation } \\
\hline Emergent & 0.52 & 0.02 & 17 & -0.23 & 0.35 & 17 & 0.21 & 0.36 & 20 & 0.12 & 0.58 & 20 \\
\hline Submergent & -0.35 & 0.14 & 17 & 0.03 & 0.92 & 17 & 0.07 & 0.25 & 20 & -0.42 & 0.05 & 20 \\
\hline \multicolumn{13}{|l|}{ Physicochemical PCs } \\
\hline PC1 & 0.33 & 0.17 & 17 & 0.21 & 0.38 & 17 & 0.28 & 0.23 & 20 & 0.01 & 0.95 & 20 \\
\hline $\mathrm{PC} 2$ & 0.43 & 0.07 & 17 & 0.13 & 0.60 & 17 & 0.34 & 0.14 & 20 & 0.44 & 0.05 & 20 \\
\hline PC3 & 0.43 & 0.07 & 17 & 0.24 & 0.32 & 17 & 0.23 & 0.33 & 20 & 0.17 & 0.48 & 20 \\
\hline \multicolumn{13}{|c|}{ Invertebrate abundance PCs } \\
\hline PC1 & 0.16 & 0.52 & 17 & -0.63 & 0.004 & 17 & -0.06 & 0.78 & 20 & -0.34 & 0.12 & 20 \\
\hline $\mathrm{PC} 2$ & 0.01 & 0.95 & 17 & -0.21 & 0.38 & 17 & 0.20 & 0.37 & 20 & -0.19 & 0.40 & 20 \\
\hline PC3 & -0.07 & 0.78 & 17 & -0.16 & 0.52 & 17 & -0.16 & 0.49 & 20 & 0.13 & 0.56 & 20 \\
\hline LMB CPUE & 0.45 & 0.05 & 17 & 0.22 & 0.36 & 17 & 0.83 & 0.0002 & 14 & -0.21 & 0.44 & 14 \\
\hline LMB PSD & -0.62 & 0.006 & 16 & 0.004 & 0.99 & 16 & -0.49 & 0.09 & 11 & 0.35 & 0.25 & 11 \\
\hline NOP CPUE & 0.03 & 0.94 & 9 & -0.44 & 0.17 & 9 & -0.26 & 0.42 & 10 & -0.005 & 0.98 & 10 \\
\hline NOP PSD & 0.06 & 0.91 & 4 & -0.06 & 0.90 & 4 & 0.60 & 0.21 & 4 & -0.43 & 0.40 & 4 \\
\hline
\end{tabular}

tionship was not significant after Bonferroni correction. However, submergent vegetation was not related to bluegill or yellow perch PC scores (Table $6)$. Only three lakes had floating vegetation and this variable was thus excluded from further analyses.

\section{Predator-Prey Relationships}

Largemouth bass populations with high size structure and low relative abundance in Nebraska sandhill lakes were associated with a lower quality of bluegill and yellow perch populations. Bluegill PC1 was negatively associated with largemouth bass PSD and tended to increase with largemouth bass CPUE (Table 6; Figure 1). Yellow perch PC1 increased with the CPUE of largemouth bass and tended to decrease with largemouth bass PSD (Table 6). Northern pike CPUE and PSD were not related to the $\mathrm{PC} 1$ or $\mathrm{PC} 2$ of either bluegill or yellow perch (Table 6). However, low sample size precluded us from estimating northern pike PSD in all but six lakes.

\section{Invertebrate Relationships}

High bluegill condition was associated with high Daphnia and Cyclops abundances, but yellow perch condition and quality were not related to zooplankton or macroinvertebrate abundances. Bluegill PC2 was inversely related to invertebrate PC1 (Table 6; Figure 2). However, no other relations between bluegill or yellow perch PC scores and invertebrate PC scores were found (Table 6).

\section{Best Predictors of Panfish Quality}

Bluegill and yellow perch quality were strongly influenced by largemouth bass and invertebrate abundances. Our best one-variable model for bluegill PC1 was BGPC1 = $2.46-0.04$ (largemouth bass PSD) $\left(r^{2}=0.38 ; \mathrm{df}=1,16 ; P=0.006\right)$. High bluegill PC1 scores were associated with low largemouth bass PSD. Invertebrate PC1 was the best predictor of bluegill PC2: 0.003-0.44(invertebrate PC1) $\left(r^{2}=0.40\right.$; df $\left.=1,17 ; P=0.004\right)$. High bluegill PC2 scores (indicating low bluegill condition) were inversely related to invertebrate $\mathrm{PC} 1$, an index of zooplankton abundance. Yellow perch PC1 was strongly related to largemouth bass CPUE: yellow perch PC1 $=-1.39+0.02$ (largemouth bass CPUE) $\left(r^{2}=0.67\right.$;f $=1,13 ; P=$ 0.0002). High quality of perch populations was most strongly related to high largemouth bass abundance. No model was significantly related to yellow perch PC2, an index of perch condition.

\section{Discussion}

Our results suggest that bluegill and yellow perch growth, condition, and size structure in the Nebraska sandhill lakes were not density dependent, perhaps because the range of these population characteristics was limited. Similarly, Tomcko (1997) did not find any evidence of density-dependent growth for bluegills in Minnesota lakes. However, small impoundments with high bluegill biomass ( $>112$ kg/ha; Novinger and Legler 1978) typically hosted populations with low size struc- 

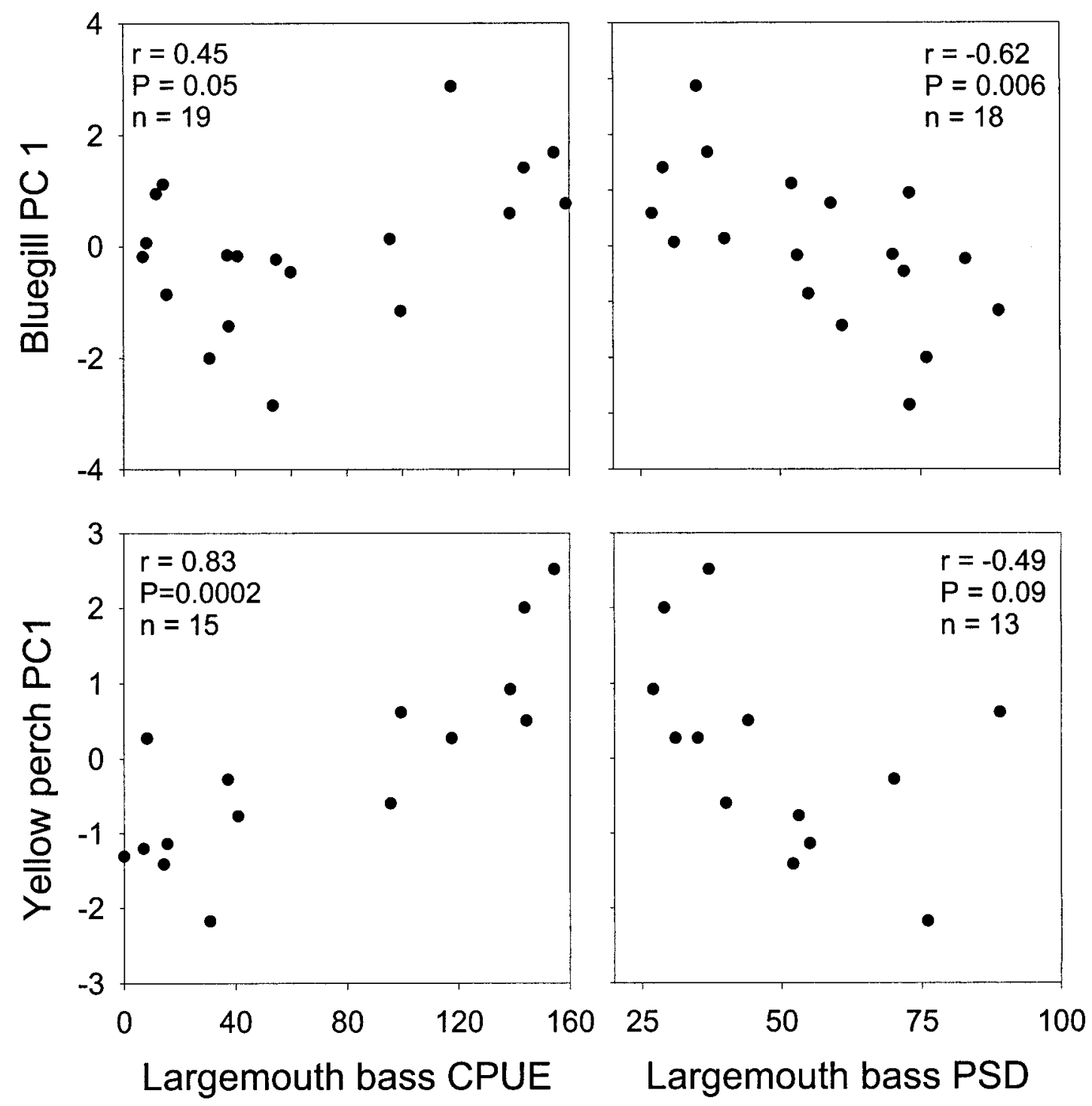

FIGURE 1.-Relationships between principal component 1 (PC1) for yellow perch and bluegill and largemouth bass catch per unit effort (CPUE; number of bass $\geq 20 \mathrm{~cm}$ collected per hour of electrofishing) and proportional stock density (PSD) in Nebraska sandhill lakes sampled in 1998 and 1999. Yellow perch populations with high relative abundance, size structure, condition, and growth scored high on yellow perch PC1, whereas bluegill populations with high relative abundance, size structure, and growth scored high on bluegill PC1.

ture (PSD < 20) and reduced growth (Weiner and Hanneman 1982; Guy and Willis 1990). Although there is experimental evidence that the growth of yellow perch may be density dependent (Hanson and Leggett 1985), our results suggest that increased yellow perch abundance was not detrimental to yellow perch quality in Nebraska sandhill lakes, at least within the range of relative abundance encountered inour study.

Our results indicate that quality bluegill popu- lations do not preclude the existence of quality yellow perch populations. In lakes where bluegill relative abundance, condition, and size structure were high, yellow perch relative abundance, condition, and size structure were also high. Foraging behaviors of the two species may be sufficiently different that interactions are minimal, or the biomass of food resources may have been sufficiently high to support the growth of both species.

Our correlative relationships between bluegill 


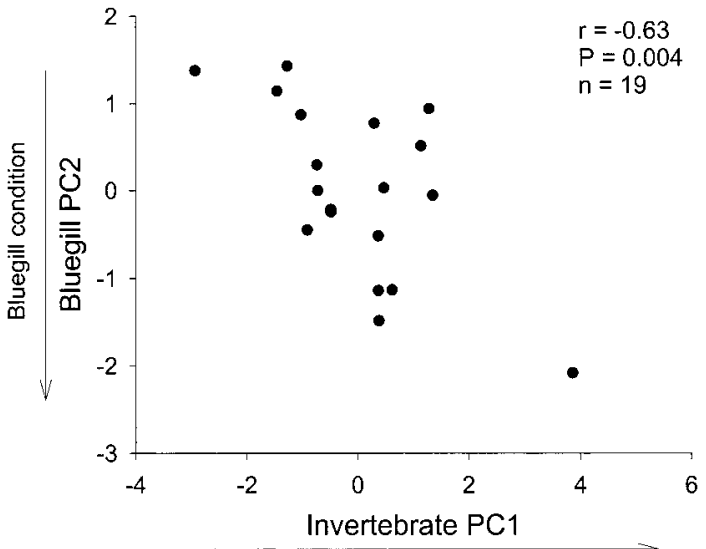

Daphnia, Chydorus, and Cyclops abundance

FIGURE 2.-Correlation between bluegill principal component 2 (PC2) and invertebrate PC1 in Nebraska sandhill lakes sampled in 1998 and 1999. Lakes that scored high on bluegill PC2 had bluegill populations with low condition, whereas lakes that scored high on invertebrate PC1 had high zooplankton abundance.

condition and zooplankton abundance suggest that bluegills may consume zooplankton, particularly Daphnia, Chydorus, and Cyclops. Other studies have suggested that Daphnia are a common food source for bluegills (Mittelbach 1988), even for fish larger than $20 \mathrm{~cm}$ (Schneider 1999). In our study, yellow perch quality and condition were not related to invertebrate abundance, although these fish commonly consume macroinvertebrates (Lott 1991; Keast and Fox 1992). If, in fact, our results indicate food habits, larger bluegills $(>15-20 \mathrm{~cm})$ may consume zooplankton, as suggested by others (Harris et al. 1999; Schneider 1999). Further analysis of food habits or bioenergetic modeling is needed to substantiate our findings.

Our results suggest that bluegill quality was more strongly associated with emergent vegetation than submergent vegetation in Nebraska sandhill lakes. However, yellow perch quality was not related to either submergent or emergent vegetation coverage. In contrast to our findings, other studies suggested that increased submergent vegetation was associated with increased abundance of bluegills (Hinch and Collins 1993) and yellow perch (Lott 1991; Lucchesi 1991) and reduced bluegill (Theiling 1990; Trebitz et al. 1997; Olson et al. 1998; Pothoven et al. 1999) and yellow perch (Lott 1991) growth. However, Radomski et al. (1995) found no difference in bluegill abundance after vegetation removal in a Minnesota lake. Schneider (1999) also suggested that increased submergent vegetation may not be detrimental to Michigan bluegill populations when harvest is low (1-3\% exploitation) and food supply is adequate, which may be the situation in Nebraska sandhill lakes. The positive trend we found between bluegill quality and emergent vegetation coverage likely is not cause and effect. Emergent vegetation may provide adequate prey (Schramm and Jirka 1989) or refuge from predators. Nonetheless, our correlative results suggest that sandhill lakes with higher emergent vegetation coverage may be capable of producing higher-quality bluegill populations.

Based on our results, largemouth bass apparently play an integral role in structuring the quality of bluegill and yellow perch populations in Nebraska sandhill lakes. High relative abundance of largemouth bass smaller than $30 \mathrm{~cm}$ was associated with increased bluegill quality in sandhill lakes, which agrees with other studies that suggested a high abundance of smaller largemouth bass may feed on smaller yellow perch (Guy and Willis 1991) and bluegills (Novinger and Legler 1978; Gabelhouse 1984; Guy and Willis 1990; Otis et al. 1998; Schneider 1999). Yellow perch quality in our study was influenced more by largemouth bass abundance than by largemouth bass size structure, thereby suggesting that a wide range of sizes of largemouth bass may feed on more fusiform yellow perch (Starostka et al. 1996; Walter 2000). The role of northern pike in sandhill lakes was hard to identify, because we collected over 20 northern pike in just eight lakes. Northern pike consume bluegills and yellow perch (Sammons et al. 1994; Gurtin et al. 1996) and may reduce the abundance and size structure of yellow perch (Anderson and Schupp 1986), but they cannot control overabundant bluegill populations (Beyerle 1971).

Factors not measured in this study may also influence panfish quality. Because exploitation was low $(<10 \%)$, fast-growing panfish were not harvested from the population, thus potentially creating a higher proportion of larger fish. In addition, winterkill may reduce the abundance of fishes in these lakes, lessening the effects of competition and increasing growth and condition. However, winterkills were not observed in our study lakes in the last 10 years, and usually only occur once in 10 years in Nebraska sandhill lakes (McCarraher 1977). However, it is possible that winter mortality of juvenile panfishes was not easily observed.

Largemouth bass appear to be an influential predator in these shallow, natural lakes in the Nebraska sandhills. As in small Michigan lakes (Schneider 1999), high submergent vegetation 
coverage (up to $97 \%$ in sandhill lakes) was not detrimental to panfish quality. Low $(<10 \%)$ exploitation and adequate food supply, which most likely occurred in many sandhill lakes, may also allow development of quality bluegill populations (Schneider 1999). Therefore, productive lakes with low harvest of panfish, coupled with highdensity largemouth bass populations, will most likely produce quality yellow perch and bluegill populations in Nebraska sandhill lakes.

\section{Acknowledgments}

We would like to thank P. Chvala, H. Fullhart, B. Heikes, and J. Harrington, South Dakota State University, and A. Glidden and M. Wilson, Nebraska Game and Parks Commission, for field and laboratory assistance. D. Hartman and the Valentine State Fish Hatchery provided housing and logistical support. Valentine and Crescent Lake National Wildlife Refuges allowed access to some study lakes. This manuscript was improved by comments from D. Isermann and three anonymous reviewers. The project was funded by the Nebraska Game and Parks Commission through Federal Aid in Sport Fish Restoration Project Number F-118$\mathrm{R}$. This paper was approved for publication by the South Dakota Agricultural Experiment Station as Journal Series 3245.

\section{References}

Anderson, D. D. W., and D. H. Schupp. 1986. Fish community responses to northern pike stocking in Horseshoe Lake, Minnesota. Minnesota Department of Natural Resources, Section of Fisheries Investigational Report 387, St. Paul.

Anderson, R. O. 1976. Management of small warmwater impoundments. Fisheries 1(6):5-7, 26-28.

Anderson, R. O., and R. M. Neumann. 1996. Length, weight, and associated structural indices. Pages 447-482 in B. R. Murphy and D. W. Willis, editors. Fisheries techniques, 2nd edition. American Fisheries Society, Bethesda, Maryland.

Beyerle, G. B. 1971. A study of two northern pikebluegill populations. Transactions of the American Fisheries Society 100:69-73.

Colle, D. E., J. V. Shireman, W. T. Haller, J. C. Joyce, and D. E. Canfield, Jr. 1987. Influence of hydrilla on harvestable sport-fish populations, angler use, and angler expenditures at Orange Lake, Florida. North American Journal of Fisheries Management 7:410-417.

Freund, R. J., and R. C. Littell. 1991. SAS system for regression, 2nd edition. SAS Institute, Cary, North Carolina.

Gabelhouse, D. W., Jr. 1984. A length-categorization system to assess fish stocks. North American Journal of Fisheries Management 4:273-285.
Gurtin, S. D., M. L. Brown, and C. G. Scalet. 1996. Food habits of northern pike and largemouth bass in small prairie impoundments. Pages 73-85 in R. Soderberg, editor. Warmwater workshop proceedings: esocid management and culture. Northeastern Division, American Fisheries Society, Bethesda, Maryland.

Guy, C. S., and D. W. Willis. 1990. Structural relationships of largemouth bass and bluegill populations in South Dakota ponds. North American Journal of Fisheries Management 10:338-343.

Guy, C. S., and D. W. Willis. 1991. Evaluation of largemouth bass-yellow perch communities in small South Dakota impoundments. North American Journal of Fisheries Management 11:43-49.

Hanson, J. M., and W. C. Leggett. 1982. Empirical prediction of fish biomass and yield. Canadian Journal of Fisheries and Aquatic Sciences 39:257-263.

Hanson, J. M., and W. C. Leggett. 1985. Experimental and field evidence for inter- and intraspecific competition in two freshwater fishes. Canadian Journal of Fisheries and Aquatic Sciences 42:280-286.

Harris, N. J., G. F. Galinat, and D. W. Willis. 1999. Seasonal food habits of bluegills in Richmond Lake, South Dakota. Proceedings of the South Dakota Academy of Science 78:79-85.

Hayes, F. R., and E. H. Anthony. 1964. Productive capacity of North American lakes as related to the quantity and the trophic level of fish, the lake dimensions, and the water chemistry. Transactions of the American Fisheries Society 93:53-57.

Hinch, S. G., and N. C. Collins. 1993. Relationships of littoral fish abundance to water chemistry and macrophyte variables in central Ontario lakes. Canadian Journal of Fisheries and Aquatic Sciences 50:18701878.

Jackson, D. C., and N. J. Brown-Peterson. 1997. Habitat, accessibility, and watershed variables as they relate to largemouth bass and bluegill in Mississippi national forest impoundments. Proceedings of the Southeastern Association of Fish and Wildlife Agencies 49(1995):26-36.

Jenkins, R. M. 1982. The morphoedaphic index and reservoir fish production. Transactions of the American Fisheries Society 111:133-140.

Johnson, D. E. 1998. Applied multivariate methods for data analysis. Duxbury Press, Pacific Grove, California.

Jones, J. R., and M. V. Hoyer. 1982. Sportfish harvest predicted by summer chlorophyll $a$ concentration in Midwestern lakes and reservoirs. Transactions of the American Fisheries Society 111:176-179.

Keast, A., and M. G. Fox. 1992. Space use and feeding patterns of an offshore fish assemblage in a shallow mesotrophic lake. Environmental Biology of Fishes 34:159-170.

Lind, O. T. 1985. Handbook of common methods in limnology, 2nd edition. Kendall Hunt, Dubuque, Iowa.

Lott, J. P. 1991. Food habits of yellow perch in eastern South Dakota lakes. Master's thesis. South Dakota State University, Brookings. 
Lucchesi, D. O. 1991. Investigation of yellow perch population dynamics in eastern South Dakota lakes. South Dakota Department of Game, Fish, and Parks, Fisheries Completion Report 92-1, Pierre.

McCarraher, D. B. 1977. Nebraska's sandhills lakes. Nebraska Game and Parks Commission, Federal Aid in Sport Fish Restoration, Project F-54-R, Completion Report, Lincoln.

Mittelbach, G. G. 1988. Competition among refuging sunfishes and the effects of fish density on littoral zone invertebrates. Ecology 69:614-623.

Novinger, G. D., and R. E. Legler. 1978. Bluegill population structure and dynamics. Pages 37-49 in G. D. Novinger and J. G. Dillard, editors. New approaches to the management of small impoundments. American Fisheries Society, North Central Division, Special Publication 5, Bethesda, Maryland.

Olson, M. H., S. R. Carpenter, P. Cunningham, S. Gafny, B. R. Herwig, N. P. Nibbelink, T. Pellett, C. Storlie, A. S. Trebitz, and K. A. Wilson. 1998. Managing macrophytes to improve fish growth: a multi-lake experiment. Fisheries 23(2):6-12.

Otis, K. J., R. R. Piette, J. E. Keppler, and P. W. Rasmussen. 1998. A largemouth bass closed fishery to control an overabundant bluegill population in a Wisconsin lake. Journal of Freshwater Ecology 13: 391-403.

Paukert, C. P., and D. W. Willis. 2000. Factors influencing panfish populations in Nebraska sandhill lakes. Nebraska Game and Parks Commission, Federal Aid in Sport Fish Restoration, Project Number F-118-R, Study 1, Job 1, Completion Report, Lincoln.

Pothoven, S. A., B. Vondracek, and D. L. Pereira. 1999. Effects of vegetation removal on bluegill and largemouth bass in two Minnesota lakes. North American Journal of Fisheries Management 19:748-757.

Rabeni, C. F. 1996. Invertebrates. Pages 335-351 in B. R. Murphy and D. W. Willis, editors. Fisheries techniques, 2nd edition. American Fisheries Society, Bethesda, Maryland.

Radomski, P. J., T. J. Goeman, and P. D. Spencer. 1995. The effects of chemical control of submerged vegetation on the fish community of a small Minnesota centrarchid lake. Minnesota Department of Natural Resources, Section of Fisheries Investigational Report 442, St. Paul.

Ricker, W. L. 1975. Computation and interpretation of biological statistics of fish populations. Fisheries Research Board of Canada Bulletin 191.

Ryder, R. A. 1965. A method for estimating the potential for fish production in north-temperate lakes. Transactions of the American Fisheries Society 94:214218.

Sammons, S. M., C. G. Scalet, and R. M. Neumann. 1994. Seasonal and size-related changes in the diet of northern pike from a shallow prairie lake. Journal of Freshwater Ecology 9:321-329.

SAS Institute. 1996. SAS/SAT user's guide for personal computers, version 6. SAS Institute, Cary, North Carolina.

Schneider, J. C. 1999. Dynamics of quality bluegill populations in two Michigan lakes with dense vegetation. North American Journal of Fisheries Management 19:97-109.

Schramm, H. L., Jr., and K. J. Jirka. 1989. Epiphytic macroinvertebrates as a food resource for bluegills in Florida lakes. Transactions of the American Fisheries Society 118:416-426.

Sokal, R. R., and F. J. Rohlf. 1995. Biometry, 3rd edition. Freeman, New York.

Starostka, A. B., B. E. Van Zee, and D. W. Willis. 1996. Food habits of largemouth bass and walleyes in Lake Cochrane, South Dakota. South Dakota Department of Game, Fish, and Parks, Fisheries Division Report 96-5, Pierre.

Theiling, C. H. 1990. The relationships between several limnological factors and bluegill growth in Michigan lakes. Master's thesis. University of Michigan, Ann Arbor.

Tomcko, C. M. 1997. Bluegill growth rates in Minnesota. Minnesota Department of Natural Resources, Section of Fisheries Investigational Report Number 458, St. Paul.

Trebitz, A. S., S. Carpenter, P. Cunningham, B. Johnson, R. Lillie, D. Marshall, T. Martin, R. Narf, T. Pellett, S. Stewart, C. Storlie, and J. Unmuth. 1997. A model of bluegill-largemouth bass interactions in relation to aquatic vegetation and its management. Ecological Modeling 94:139-156.

Walter, D. D. 2000. Food habits of walleye and saugeye when stocked as secondary predators into small South Dakota impoundments. Master's thesis. South Dakota State University, Brookings.

Weiner, J. G., and W. R. Hanneman. 1982. Growth and condition of bluegills in Wisconsin lakes: effects of population density and lake $\mathrm{pH}$. Transactions of the American Fisheries Society 111:761-767. 